\title{
Derma-Membrane-Structure Topical Cream
}

National Cancer Institute

\section{Source}

National Cancer Institute. Derma-Membrane-Structure Topical Cream. NCI Thesaurus.

Code C78835.

A topical cream formulation containing physiological lipids with potential anti-xerotic activity. Derma-membrane-structure topical cream contains ing redients that mirror the lipid component of the skin, including hydrated phosphatidyl choline, but does not contain conventional emulsifiers that may disrupt the skin-lipid barrier. This cream can also be used as a vehicle or base for topically applied medications. 